\title{
THE IMPACT OF EXTRUSION ON THE BIOGAS AND BIOMETHANE YIELD OF PLANT SUBSTRATES
}

\section{Krzysztof Pilarski ${ }^{1}$, Agnieszka Anna Pilarska2 ${ }^{2}$, Kamil Witaszek' ${ }^{1}$ Zbigniew Dworecki ${ }^{1}$, Tomasz Żelazińskiं ${ }^{3}$, Adam Ekielski ${ }^{3}$, Agnieszka Makowska² ${ }^{2}$ Jan Michniewicz ${ }^{2}$}

1 Institute of Biosystems Engineering, Poznan University of Life Sciences, Wojska Polskiego 28, 60-637 Poznań, Poland, e-mail: pilarski@up.poznan.pl,witaszek@up.poznan.pl,dworecki@up.poznan.pl

2 Institute of Food Technology of Plant Origin, Poznan University of Life Sciences, Wojska Polskiego 28, 60-637 Poznań, Poland, e-mail: pilarska@up.poznan.pl, agmak@up.poznan.pl, michniej@up.poznan.pl

3 Department of Production Organization and Engineering, Warsaw University of Life Sciences - SGGW, Nowoursynowska 164, 02-787 Warszawa, Poland, e-mail: tomasz_zelazinski@sggw.pl, adam_ekielski@sggw.pl

* Corresponding author's e-mail: pilarska@up.poznan.pl

Received: 2016.06.09 Accepted: 2016.08.08 Published: 2016.09.20

\begin{abstract}
The objective of the present work was to determine the effect of pretreatment by extrusion on the biogas and biomethane yield of lignocellulosic substrates such as maize silage and maize straw silage. The biogas yields of the substrates before and after treatment were compared. Moreover, energy efficiency of pretreatment by extrusion was analyzed in order to assess the applicability of the process in an agricultural biogas plant. Extrusion tests were carried out in a short single-screw extruder KZM-2 in which the length-to-diameter ratio of the screw was 6:1 and rotational speed was $200 \mathrm{rpm}$. The biogas yield tests of the plant substrates after extrusion were carried out in a laboratory scale, using 15 biofermenters operated in a periodic manner, at a constant temperature of $39^{\circ} \mathrm{C}$ (mesophilic digestion) and controlled $\mathrm{pH}$ conditions. The gas-emission analysis was performed using a certified gas analyzer from Geotech GA5000. Pretreatment by extrusion was observed to improve the quantity of methane generated: in terms of fresh matter for maize silage subjected to extrusion, the methane yield was $16.48 \%$ higher than that of the non-extruded silage. On the other hand, maize straw silage after extrusion gave $35.30 \%$ more methane than did the same, non-extruded, material. Differences in yields relative to dry organic matter are also described in this paper. Taking into account the amount of energy that is spent on pretreatment and the generated amount of methane, the energy balance for the process gives an idea of the economics of the operation. For maize silage, energy efficiency was lower by $13.21 \%(-553.2 \mathrm{kWh} / \mathrm{Mg})$, in contrast to maize straw silage, where the increase in energy was $33.49 \%(678.4 \mathrm{kWh} / \mathrm{Mg})$. The obtained results indicate that more studies on the pretreatment and digestion of maize silage are required in order to improve the efficiency of its use for making biogas. To fully utilize its potential, it is necessary to know thoroughly the effect of the extrusion process and of biogas production on energy efficiency at different conditions.
\end{abstract}

Keywords: extrusion, lignocellulosic biomass, anaerobic digestion, biomethane yield, economic balance. 


\section{INTRODUCTION}

New biogas substrates are sought now and again to be used as successful replacements for maize silage. Maize silage as a substrate for the obtaining of biogas, even though characterized by high biogas yields in the range $200-250 \mathrm{~m}^{3} /$ Mg FM [Pilarska et al., 2015], is not the optimum starting material for use in agricultural biogas plants. Those using maize silage are characterized by low profit or even a loss on business. This is the consequence of high cost of the starting material (as high as PLN 150/Mg of fresh matter for maize silage) or is connected with high cost of farming and harvesting works and of the silage making process itself. The substrates which could possibly replace maize silage include vegetable waste arising in farms such as rape straw, maize straw, triticale straw, or energy plants such as: cup plant (Silphium perfoliatum), Virginia fanpetals (Sida hermaphrodita), sorghum, or miscanthus [Witaszek et al., 2015a]. The materials are so-called lignocellulosic substrates, mainly consisting of hardly-digestible lignocellulosic fibers (Figure 1). Their lignin component is a polymer composed of monomers in the form of derivatives of phenolic alcohols (coniferyl, sinapyl, and coumaryl alcohols) and it encapsulates cellulose - a decomposable polysaccharide which is composed linearly of molecules of D-glucose and hemicellulose (a non-uniform groups of branched polysaccharides (comprising cellulosans, pentosans, hexosans, according to Schulze) [Witaszek et al., 2015b; Carvalheiro et al., 2008]. Lignin is hardly digestible at all in the anaerobic digestion process, therefore, the anaerobic bacteria have a very limited access to decomposable compounds (cellulose and hemicelluose). Owing to its structure, as described above, the so-called lignocellulosic biomass is very readily floatable in the digester. Moreover, it is characterized by long retention time and a relatively low biogas yield - even though it does have a content of readily digestible compounds. Therefore, it cannot be used in its original form as a substrate in agricultural biogas plants.

Anaerobic digestion is a process comprising four phases which run in parallel: hydrolysis, acidogenesis, acetogenesis, and methanogenesis. In the case of lignocellulosic substrates, hydrolysis is the essential, starting phase during which bacteria and enzymes decompose complex compounds
- including celluloses and hemicelluloses to form less complex compounds, such as glucose, mannose, galactose, and xylose [Yang et al., 2015]. However, the hydrolysis of lignocellulosic fibers is a very slow process and is limited merely to compounds which are not encapsulated by lignin as it is not decomposable.

Therefore, methods are sought which enable disintegration of lignin and release cellulose and hemicellulose, thus causing the digestion of more substrate and, thereby, lead to higher biogas and methane yields. Mechanical, chemical and biological methods are available. Mechanical processing methods include shredding, extrusion, radiation (ultrasonic, microwaves), steam explosion. Chemical treatment methods include: alkaline and acidic, steam explosion with catalyst, treatment with ionic liquids, treatment with peroxides, oxidation. Biological treatment methods are those including the use of fungi, microbes, enzymes as well as silage making [Zheng et al., 2014].

In this paper, extrusion was used as a pretreatment method for lignocellulosic biomass. Extrusion is a mechanical-thermal process in which the substrate (lignocellulosic material) is exposed to high temperatures $\left(150-200^{\circ} \mathrm{C}\right)$ and

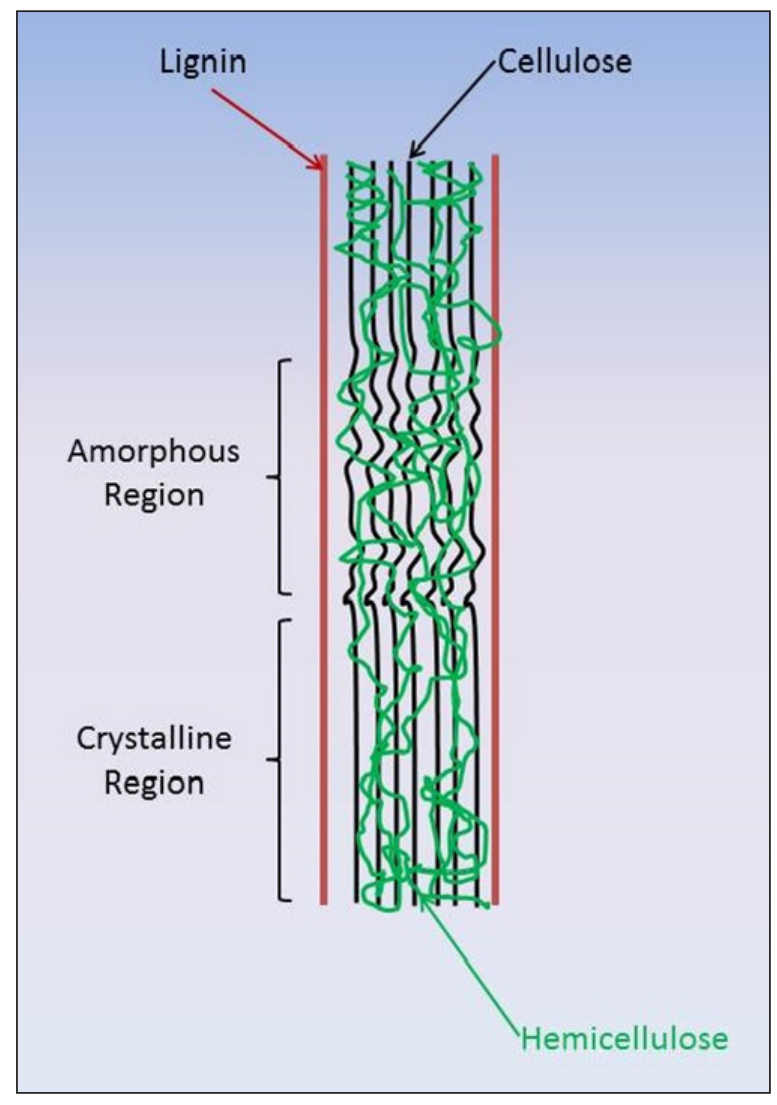

Figure 1. Lignocellulosic fiber [Witaszek et al., 2015] 
variable pressure (max. $20 \mathrm{MPa}$ ) for a short time (less than a minute) [Camire, 1998]. The process takes place in the extruder, composed of a hopper-feeder, barrel with screw, in which the biomass heating, compression and cutting take place. The extruder barrel may be provided with electric heaters to elevate temperature inside the chamber. The extruder is terminated with a heated or cooled die with a suitable outlet opening, due to which the compressed material expands and changes its structure as it is discharged from the chamber, because of the high difference in pressures in the extruder's chamber and outside [Pęksa, 2011]. This reduces the biomass particle size, breaks the lignocellulosic fibers, and leads to their prehydrolysis [Karunanithy and Muthukumarappan, 2010; Zheng et al., 2014].

The objective of this research work was to assess the effect of extrusion as a pretreatment method on the biogas and biomethane yield of lignocellulosic substrates, including maize silage and maize straw silage. The values of biogas yields for the substrates before and after treatment were compared. Data on energy efficiency were also analyzed to assess the method's applicability in agricultural biogas plants.

\section{MATERIALS AND METHODS}

\section{Substrates and inoculum}

The maize silage for use in this work was obtained from the Agriculture and Pomology Research Farm in Przybroda - one of the agricultural experimental farms maintained by the University of Life Sciences in Poznań. The maize straw silage was obtained from a farm in the Wielkopolska region by collecting the maize straw using a forage wagon with cutting knifes. After being shreeded, the maize straw was silaged in a flexible silo. The inoculum was obtained from an agricultural biogas plant, making biogas from maize silage.

\section{Pretreatment - extrusion}

The extrusion process was carried out in a short single-screw extruder KZM-2 in which the length-to-diameter ratio of the screw was 6:1 - in the Extrusion Laboratory of the Faculty of Production Engineering, University of Life Sciences in Warsaw. The process was run at the following parameters: temperature in the extruder barrel: $150^{\circ} \mathrm{C} \pm 5^{\circ} \mathrm{C}$, time of residence of material in the extruder barrel, 45 seconds. Other parameters of the extruder are shown in Table 1.

\section{Preparation of digestion mixture}

The substrate/inoculum digestion mixture was composed in accordance with VDI 4630, providing guidelines on how to carry out the process of digestion of organic materials [Norm VDI 4630, 2006]. According to the standard as well as literature reports [Parkin and Owen 1986], the author attempted to keep dry organic matter in the inoculum in the range 1.5 to $2 \%$ (limitation of organic loading rate), keep dry matter at $10 \%$ or less - so the mixture is pumpable in the biogas plant operating conditions, keep $\mathrm{pH}$ of the feed before starting the digestion process in the range 6.8 to 7.5. The composition of the digestion mixture is shown in Table 2.

Table 1. Technological parameters of the extruder KZM-2

\begin{tabular}{|l|c|}
\hline \multicolumn{1}{|c|}{ Parameter } & Value \\
\hline Motor output power $(\mathrm{kW})$ & 22 \\
\hline Heating power $(\mathrm{kW})$ & 3 \\
\hline L/D $(-)$ & $6: 1$ \\
\hline Rotational speed of screw $(\mathrm{rpm})$ & 200 \\
\hline Die hole diameter $(\mathrm{mm})$ & 8 \\
\hline Compression ratio $(-)$ & 1.5 \\
\hline Capacity $(\mathrm{kg} / \mathrm{h})$ & $70-110$ \\
\hline
\end{tabular}

Table 2. Composition of the digestion mixtures

\begin{tabular}{|l|c|c|c|}
\hline \multicolumn{1}{|c|}{ Substrate } & Substrate mass $(\mathrm{g})$ & Inoculum mass $(\mathrm{g})$ & $\mathrm{pH}$ \\
\hline Inoculum & - & 1200 & 7.96 \\
\hline Maize silage & 100 & 1100 & 7.32 \\
\hline Extruded maize silage & 30 & 1150 & 7.81 \\
\hline Maize straw silage & 50 & 1170 & 7.97 \\
\hline Extruded maize straw silage & 30 & 7.95 & \\
\hline
\end{tabular}




\section{Biogas production set-up and procedure}

Studies on the biogas yields of substrates pretreated by extrusion were carried out with the use of biofermenters designed in the Institute of Biosystems Engineering. Biogas production as well as biogas and methane yield analyses were carried out in accordance with the German standard DIN 38 414-S8 [Norm DIN 38 414-S8, 1985]. The tests were carried out in 3 repetitions ( 3 compartments each for maize silage before and after extrusion, 3 compartments each for maize straw silage before and after extrusion, and 3 compartments for the control). A biofermenter with 3 compartments is shown in Figure 2.

The biofermenters (4) are provided with a water jacket (3), enabling its temperature to be kept at a constant level of $38 \pm 2^{\circ} \mathrm{C}$ by means of a heater (1). The biogas product was stored in tanks filled with a neutral liquid (7) which prevents dissolution of gas in it and of which the level is the lower the more biogas is produced. The obtained gas volume was measured every 24 hours. Pursuant to the provisions of VDI 4630, tests for a given substrate were continued until the daily biogas output fell below $1 \%$ of the total amount of biogas. The biogas and biomethane yield for a given substrate were calculated as a difference

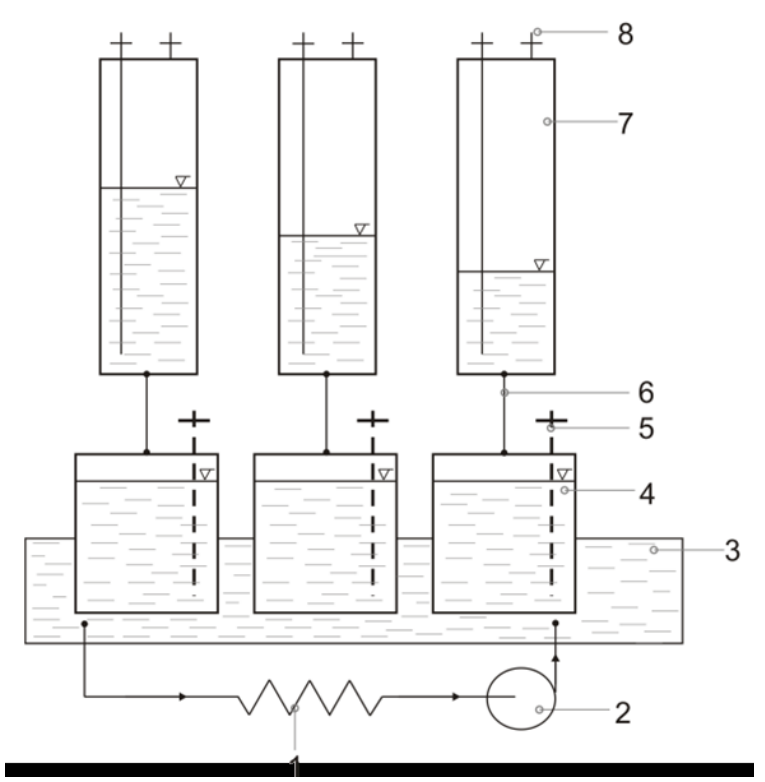

Figure 2. Biofermenter for biogas production tests (3-chamber section): 1 - water heater with temperature adjustment, 2 - water pump, 3 - water jacket $\left(39^{\circ} \mathrm{C}\right)$, 4 - biofermenter (1.4 dm3), 5 - slurry-sample drawing tube, 6 - tube for transporting the biogas formed, 7 - graduated tank for biogas, 8 - gas sampling valve [Pilarska et al., 2016] between the biogas volume obtained from the substrate/inoculum mixture and the gas volume obtained from the inoculum alone (in the control test) [Pilarska et al., 2016].

\section{Analytical methods}

The substrates and inoculum were analyzed according to Polish standards: dry mass/humidity (drier method PN-75 C-04616/01), organic matter and ash (incineration according to the modified PN-Z-15011-3), pH (potentiometric method PN-90/A-75101.06), conductivity (PNEN 27888:1999), using laboratory meter CP-411 from ELMETRON, and analysis of the content of lignin, cellulose and hemicellulose. The analysis of lignin, cellulose and hemicellulose was carried out in accordance with PN-92/P-50092, using the methodology described by Stolarski et al. [2013].

Measurements of the concentration of methane, carbon dioxide, sulfur hydride, ammonia and - as control - oxygen in the biogas product were carried out using the gas analyzer from Geotech GA5000. Its operating ranges are as follows: $\mathrm{O}_{2} 0-25 \%, \mathrm{CO}_{2} 0$ $100 \%, \mathrm{CH}_{4} 0-100 \%$; $\mathrm{NH}_{3} 0-1000 \mathrm{ppm}$ and $\mathrm{H}_{2} \mathrm{~S}$ $0-10,000 \mathrm{ppm}$. The gas monitoring system was calibrated once a week using calibrating mixtures from Air Products.

\section{Energy calculation}

The energy balance for the extrusion process was calculated from the formulae (1) and (2) [Uellendahl, 1998]. The amount of additional electric or thermal energy, obtained from a pretreated biomass $\left(E_{b}\right)$ with the mass $M_{b}$ is calculated from the following formula:

$$
E_{b}=W E M \cdot n \cdot V_{C_{4}} \cdot M_{b}
$$

where: $W E M$ - value of energy for methane 9.56 $\left(\mathrm{kWh} / \mathrm{m}^{3}\right)$;

$V_{\mathrm{CH}_{4}}$ - increase in the amount of methane after substrate treatment $\left(\mathrm{m}^{3} / \mathrm{Mg}\right.$ d.m.) or, in other words, the difference between the quantities of methane obtained from the substrate before extrusion and after extrusion; $M_{b}$ - mass of treated substrate $(\mathrm{Mg})$;

$n$ - energy efficiency of a cogeneration engine, which was $32-48.7 \%$.

The energy consumption by the extruder, $E_{m}$, was calculated from the following formula: 


$$
E_{m}=P \cdot W^{-1}
$$

where: $E_{m}$ - electric energy consumed by the extruder (kWh);

$P$ - extruder's output power $(\mathrm{kW})$;

$W$ - extruder's capacity $(\mathrm{Mg} / \mathrm{h})$

\section{RESULTS AND DISCUSSION}

Table 3 shows the essential physico-chemical parameters for the substrates used in the experiment - with and without extrusion.

Owing to the extrusion process the dry matter content increased by nearly $9 \%$ for maize silage and - much less, by about $2 \%$ - for maize straw silage. The changes are the consequence of differences in the original structure of the two plant materials - more specifically a higher water content and the fact that the process of its release from the intercellular space takes place more readily in the case of corn silage. The change in the dry organic matter for maize silage and maize straw silage after extrusion was very slight (increase by $1.22 \%$ and $3.52 \%$, respectively). While the $\mathrm{pH}$ values for maize silage are comparable, in the case of maize straw the $\mathrm{pH}$ shifted towards a slightly acidic range as the result of pretreatment ( $\mathrm{pH}$ of 8.55 shifted to 6.33).

Table 4 is a summary of percentages of the contents of lignocellulosic compounds in the test materials.

The analyses indicate a slight, bidirectional change in the lignin content in the samples as the result of the extrusion. For the maize silage, the extrusion resulted in a decrease in the lignin content by $2.31 \%$. In the maize straw silage after extrusion, the lignin content was $2.69 \%$ higher than before. The data in Table 4 indicate that both cellulose and hemicellulose were lower after extrusion. Disintegration of lignin released both types of polysaccharides and led to their predecomposition due to high pressure and temperature (socalled expansion of the material took place).

The effects of changes in the physico-chemical parameters and the content of polymer building materials of the test plant substrates are best seen in the studies on biogas and biomethane yield carried out for each sample.

Table 5 shows the cumulative biogas and biomethane yield for the lignocellulosic substrates in terms of fresh matter $\left(\mathrm{m}^{3} / \mathrm{Mg}\right.$ f.m.) and dry organic matter $\left(\mathrm{m}^{3} /\right.$ d.o.m.). A reference of yield to fresh matter is important from the economic and logistic points of view: showing the actual yield of biogas obtained from the material, it is the most practical piece of information for a business person contemplating investment in an agricultural biogas plant. On the other hand, conversion of yield into dry organic matter determines the theoretical yield of a substrate, taking into account its physico-chemical characteristics.

The extrusion process led to higher methane yields for both substrates - only in terms of their fresh matter. In the case of maize silage, the methane yield increased by $16.48 \%$, and for the maize straw silage- by as much as $35.30 \%$. On the other hand, in terms of dry organic matter, the methane

Table 3. Physicochemical parameters of the substrates before and after extrusion

\begin{tabular}{|l|l|l|l|l|}
\hline \multirow{2}{*}{ Substrate } & \multicolumn{2}{l|}{ Parameters } & \multicolumn{2}{l|}{} \\
\cline { 2 - 5 } & $\mathrm{pH}$ & $\begin{array}{l}\text { Conductivity } \\
(\mathrm{mS} / \mathrm{cm})\end{array}$ & $\begin{array}{l}\text { Dry matter } \\
(\%)\end{array}$ & $\begin{array}{l}\text { Dry organic matter } \\
(\%)\end{array}$ \\
\hline Inoculum & 7.96 & 12.58 & 2.64 & 70.73 \\
\hline Maize silage & 4.01 & 1.67 & 32.06 & 95.43 \\
\hline Extruded maize silage & 3.88 & 1.56 & 41.33 & 96.65 \\
\hline Maize straw silage & 5.55 & 1.65 & 78.26 & 81.46 \\
\hline Extruded maize straw silage & 5.33 & 2.08 & 80.06 & 84.98 \\
\hline
\end{tabular}

Table 4. The content of the lignocellulosic compounds in the test plant substrates

\begin{tabular}{|c|c|c|c|}
\hline Substrate & Lignin (\%) & Cellulose (\%) & Hemicellulose (\%) \\
\hline Maize silage & 11.99 & 34.33 & 17.27 \\
\hline Extruded maize silage & 9.68 & 22.43 & 12.07 \\
\hline Maize straw silage & 23.59 & 46.24 & 17.82 \\
\hline Extruded maize straw silage & 26.28 & 36.84 & 13.51 \\
\hline
\end{tabular}




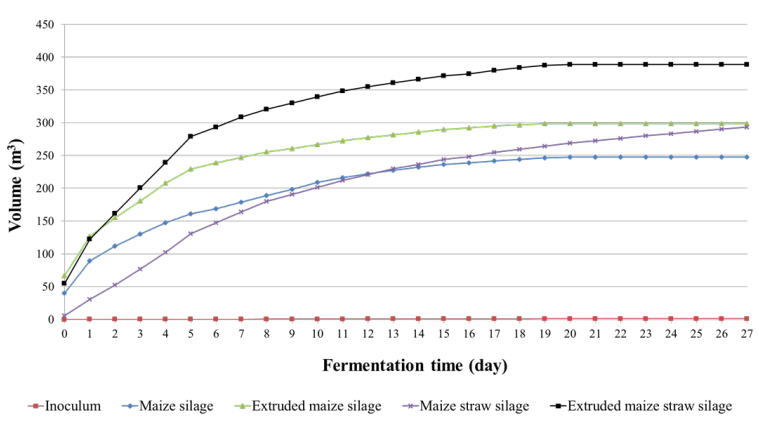

Figure 3a. Daily production of biogas from fresh matter of the tested plant substrates and inoculum

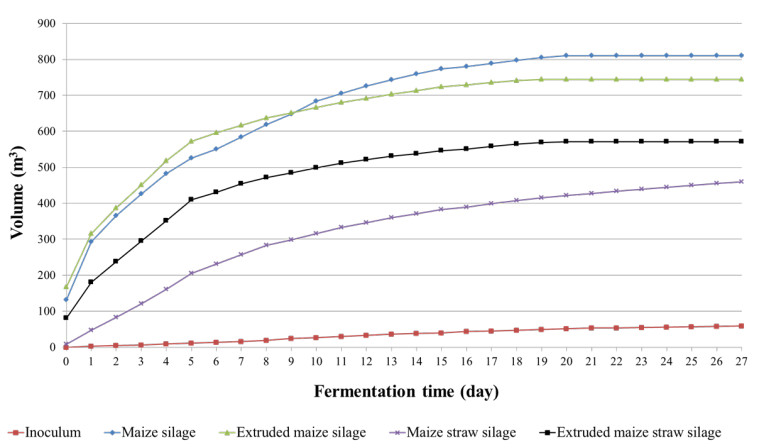

Figure 4a. Daily production of biogas from dry organic matter of the tested plant substrates and inoculum

volumes obtained from the materials were different: maize silage provided methane in a $11.03 \%$ lower amount whereas for maize straw silage, the cumulative methane yield increased by $26.79 \%$.

Figures 3 and 4 showing the daily output of biogas (Figures 3a, 4a) and methane (Figures 3b, $4 \mathrm{~b}$ ) in terms of fresh and dry organic matter, in-

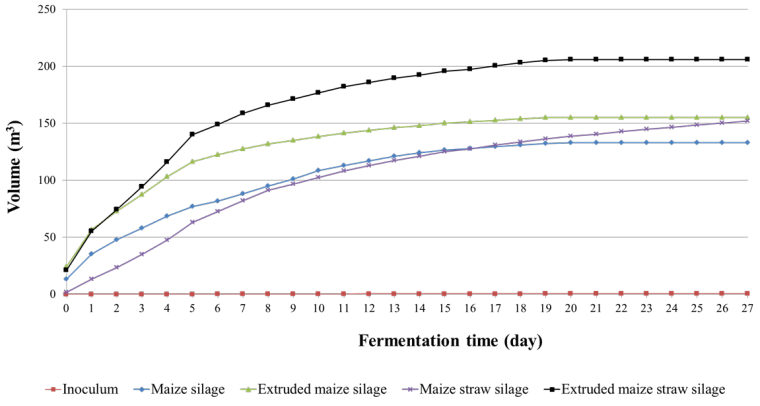

Figure 3b. Daily production of methane from fresh matter of the tested plant substrates and inoculum

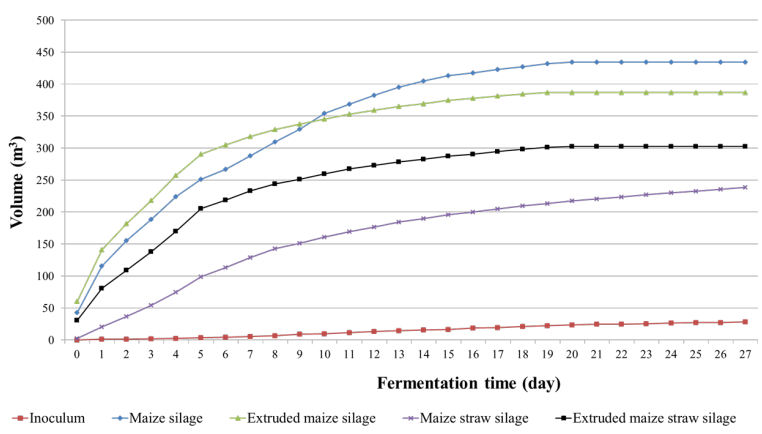

Figure 4b. Daily production of methane from dry organic matter of the tested plant substrates and inoculum

dicate that the process was running correctly. The shape of the curves corresponding to each substrate demonstrates the successive increase in the biogas and methane yield taking place every day until constant volumes were obtained. In terms of fresh matter, much higher yields were obtained for the materials after hydrothermal pretreatment.

Table 5. Cumulative methane and biogas yields from $\mathrm{Mg}$ of fresh matter and volatile solids the test plant substrates

\begin{tabular}{|c|c|c|c|}
\hline \multicolumn{4}{|c|}{ Fresh matter } \\
\hline Substrate & $\begin{array}{l}\mathrm{CH}_{4} \\
(\%)\end{array}$ & $\begin{array}{c}\text { Cumulative methane yield } \\
\left(\mathrm{m}^{3} / \mathrm{Mg} \text { f.m. }\right)\end{array}$ & $\begin{array}{c}\text { Cumulative biogas yield } \\
\left(\mathrm{m}^{3} / \mathrm{Mg} \text { f.m.) }\right.\end{array}$ \\
\hline Control $^{*}$ & 47.73 & 0.53 & 1.11 \\
\hline Maize silage & 53.66 & 133.00 & 247.86 \\
\hline Extruded maize silage & 51.93 & 154.92 & 298.35 \\
\hline Maize straw & 51.88 & 152.01 & 293.00 \\
\hline Extruded maize straw silage & 52.94 & 205.68 & 388.52 \\
\hline \multicolumn{4}{|c|}{ Dry organic matter } \\
\hline Substrate & $\begin{array}{l}\mathrm{CH}_{4} \\
(\%)\end{array}$ & $\begin{array}{c}\text { Cumulative methane yield } \\
\left(\mathrm{m}^{3} / \mathrm{Mg} \text { d.o.m. }\right)\end{array}$ & $\begin{array}{c}\text { Cumulative biogas yield } \\
\left(\mathrm{m}^{3} / \mathrm{Mg} \text { d.o.m. }\right)\end{array}$ \\
\hline Control $^{*}$ & 47.73 & 28.48 & 59.67 \\
\hline Maize silage & 53.66 & 434.75 & 810.20 \\
\hline Maize silage extrusion & 51.93 & 386.79 & 744.87 \\
\hline Maize straw & 51.88 & 238.43 & 459.57 \\
\hline Maize straw silage extrusion & 52.94 & 302.30 & 571.04 \\
\hline
\end{tabular}

* Control - defined as inoculum in this experiment 
The highest values were recorded for maize straw silage: $388.52 \mathrm{~m}^{3} / \mathrm{Mg}$ f.m. of biogas and 205.68 $\mathrm{m}^{3} / \mathrm{Mg}$ f.m. of methane (Figures 3a, b; Table 5). The curves illustrating daily yields of biogas in terms of dry organic matter of substrate (Figures $4 a, b)$ show definitely different relationships: the highest production of biogas and methane from a non-extruded maize silage $\left(810.20 \mathrm{~m}^{3} / \mathrm{Mg}\right.$ d.o.m. and $434.75 \mathrm{~m}^{3} / \mathrm{Mg}$ d.o.m., respectively). For the other samples - including the extruded ones lower process yields were obtained.

During the experiment, $\mathrm{pH}$ changes for each test sample were monitored (Figure 5). Changes in the $\mathrm{pH}$ of each substrate were in the range 7.27.8 , that is within the tolerable limits for methanogens). Decomposition times for maize silage (both extruded and non-extruded) were same and also the shortest (19 days). A slightly longer biodegradation time was observed for the extrudedmaize straw silage ( 20 days). The longest time ( 28 days) was recorded for the non-extruded maize straw silage. In principle, digestion was stable for each system, indicating the correct choice of process parameters and the high buffer capacity of the inoculum. The extrusion process accelerated the decomposition of lignocellulosic substrates; this is valuable information for improving the rate of return for a biogas plant.

In order to assess the cost-effectiveness of pretreatment by extrusion of maize silage and maize straw silage, the energy balance of the process was calculated (energy to be spent on pretreatment, as compared with the digestion process yield), in which formulae (1) and (2) are applied and the parameters shown in Table 6 are taken into account.

The energy balance takes into account biomethane yields in terms of dry organic matter. Moreover, it was assumed that the treated substrate mass $\left(\mathrm{M}_{\mathrm{b}}\right)$ is $2.4 \mathrm{Mg} / \mathrm{d}(\mathrm{d}$ - day) - the maximum amount of biomass, resulting from the extruder's capacity (W) of $0.1 \mathrm{Mg} / \mathrm{h}$, extruder's output power $(\mathrm{P})$ with the heating elements' output power of $25 \mathrm{~kW}$, and electrical efficiency of the cogeneration motor $\left(\mathrm{n}_{\text {elec }}\right)$ of $48 \%$.

Shown in Table 7 are the values of energy efficiency of the untreated and pretreated substrates as well as the percentage increase in energy and the energy increase in $\mathrm{kWh} / \mathrm{Mg}$, while taking into account energy consumption of pretreatment.

Calculations were made which indicate that the energy balance, taking into account pretreat-

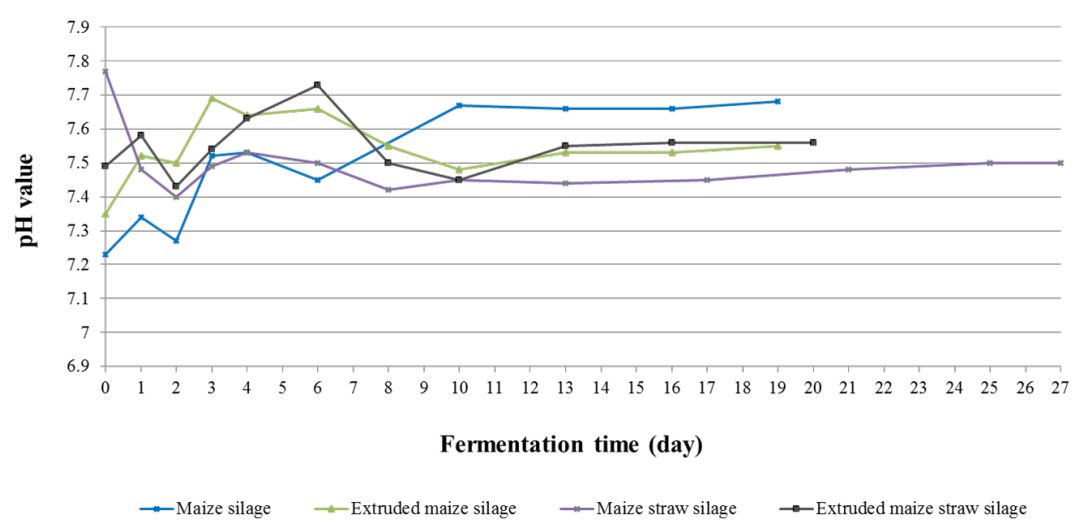

Figure 5. $\mathrm{pH}$ variation profiles for digested substrates

Table 6. Parameter values of energy balance

\begin{tabular}{|l|c|c|c|c|c|c|}
\hline \multicolumn{1}{|c|}{ Substrate } & WEM $\left(\mathrm{kWh} / \mathrm{m}^{3}\right)$ & $\mathrm{V}_{\mathrm{CH} 4}\left(\mathrm{~m}^{3} / \mathrm{Mg}\right)$ & $\mathrm{n}_{\text {elec. }}(\%)$ & $\mathrm{M}_{\mathrm{b}}(\mathrm{Mg} / \mathrm{d})$ & $\mathrm{P}(\mathrm{kW})$ & $\mathrm{W}(\mathrm{Mg} / \mathrm{h})$ \\
\hline Maize silage & 9.56 & -47.96 & 48 & 2.4 & 25 & 0.1 \\
\hline Maize straw silage & 9.56 & 63.87 & 48 & 2.4 & 25 & 0.1 \\
\hline
\end{tabular}

Table 7. Energy balance of extruded plant substrates

\begin{tabular}{|l|c|c|c|c|c|}
\hline Substrate & $\begin{array}{c}\text { Energy efficiency of } \\
\text { untreated substrate } \\
(\mathrm{kWh} / \mathrm{Mg})\end{array}$ & $\begin{array}{c}\text { Energy consumption } \\
\text { of pretreatment } \\
(\mathrm{kWh} / \mathrm{Mg})\end{array}$ & $\begin{array}{c}\text { Energy efficiency of } \\
\text { pretreated substrate } \\
(\mathrm{kWh} / \mathrm{Mg})\end{array}$ & $\begin{array}{c}\text { Energy } \\
\text { increase }(\mathrm{kWh} / \\
\mathrm{Mg})\end{array}$ & $\begin{array}{c}\text { Energy } \\
\text { increase }(\%)\end{array}$ \\
\hline Maize silage & 4188.0 & 25 & 59.8 & -553.2 & -13.21 \\
\hline Maize straw silage & 2025.9 & 25 & 2729.3 & 678.4 & 33.49 \\
\hline
\end{tabular}


ment by extrusion of maize silage, was negative $(-553.2 \mathrm{kWh} / \mathrm{Mg}$, that is $-13.21 \%)$ whereas the energy balance of maize straw silage was positive $(678.4 \mathrm{kWh} / \mathrm{Mg}$, that is $33.49 \%)$. These findings correspond to the data in Table 5, showing declining energy efficiencies after extrusion for maize silage (in terms of dry organic matter).

Cumulative methane yields were expressed in terms of dry organic matter, also in order to enable the direct assessment of extrusion; it is known to be able to increase the extrudate's dry organic matter due to evaporation of water from the hot material at the extruder's die hole. In the case of maize silage extrudate, the cumulative methane yield was observed to decrease by 11.03 $\%$ in comparison with d.o.m., see Table 5. The undesirable result could be attributed to the loss of organic matter from the material - probably the products of preliminary hydrolysis and/or volatile fatty acids - in the process of extrusion. It should be noted that the maize silage making process is accompanied by the formation of considerable amounts of fatty acids, especially lactic acid, which tend to evaporate from the extrudate at the die hole due to high temperature conditions prevailing in the extruder barrel [Bezabih and Tamir, 2014]. The hypothesis has not yet been confirmed in literature reports, therefore, the effect of extrusion on the amount of volatile fatty acids in the extrudate remains to be investigated.

In the case of pretreated maize straw, the cumulative methane yield increased by $26.79 \%$. The substrate's extrusion led to much more desirable effects: lower pressure after leaving the extruder and the effect of the extruder's screw resulted in the maize straw silage having a larger active area (as the material expanded) and partial hydrolysis of cellulose and hemicellulose. Cellulose at high temperatures is hydrolyzed to glucose, while hemicellulose to xylose, mannose and galactose [Pérez et al., 2002]. All of these, being monosaccharides, are easily and effectively decomposed, providing considerable amounts of methane.

In literature, there are reports of works describing the results of studies on the extrusion of plant substrates such as sorghum, straw, grass, and maize silage, and its impact on biogas yields for all these substrates. In studies reported by Menardo et al. [2015], extrusion of rice straw mixed with maize silage and triticale silage resulted in an increase in the methane yield by $15.7 \%$, whereas the electric energy efficiency increased from 13.4 to as much as $40.2 \mathrm{kWh}_{\mathrm{el}}$ per ton of fresh matter. The author of the above studies postulates that the phenomenon was due to the fact that the long fibers present in rice straw were more-finely shredded. Extrusion also had a positive effect on degradation of cellulose and hemicellulose, thus increasing the biogas yield. Panepinto and Genon [2016], reporting their studies on the methane yield obtained from maize silage after treatment by extrusion in a working biogas plant, found that methane yield had increased to $15 \%$, and electric energy did to $6.5 \%$. This was attributed by the authors mainly to the fact that the pretreated substrate had increased its specific area. The authors believe that studies on the effect of extrusion on the substrate's biogas yield should be continued because the pretreatment method provided desirable results and reports on similar studies are rather scarce. Such studies in future should include a larger number of substrate types because the results seem to indicate that the effect of extrusion on biogas yield depends on substrate type, among other things.

\section{CONCLUSIONS}

The values of biogas and biomethane yield of selected plant substrates were verified. The studies included maize silage and maize straw silage after pretreatment by extrusion prior to anaerobic digestion. The results were compared with the amounts of biogas and methane produced in anaerobic digestion of the same though non-extruded materials.

In terms of fresh matter, the amount of methane increased by $16.48 \%$ for maize silage and by as much as $35.30 \%$ for maize straw silage in comparison with the non-extruded substrates. In terms of dry organic matter, worse yields were obtained for maize silage (decrease by $11.03 \%$,) in contrast to maize straw silage where the yields increased desirably by $26.79 \%$ in comparison with the non-extruded samples. Such undesirable changes in yields for maize silage in terms of dry organic matter were probably attributable to the loss of organic matter in the extrusion process products of preliminary hydrolysis and/or volatile fatty acids.

The energy balance calculations do not seem to indicate an unambiguously desirable effect of extrusion on the total amount of energy produced - in relation to energy consumed in the extrusion process for the two test substrates. The energy bal- 
ance was negative (-553.2 $\mathrm{kWh} / \mathrm{Mg} ;-13.21 \%)$ for maize silage and positive for maize straw silage (678.4 kWh/Mg; 33.49\%). This indicates that further studies on the subject are required - both for investigating the effect of various extrusion process conditions on the efficiency of energy production from a given substrate and for exploring the possibility to use other substrates with a view to selecting the most efficient one.

\section{REFERENCES}

1. Camire M.E. 1998. Chemical changes during extrusion cooking: recent advances. In: Shahidi F., Ho C.T., Chuyen N. (Eds.), Process-induced chemical changes in food. Plenum Press, New York, 109-121.

2. Carvalheiro F., Duarte L.C., Gírio F.M. 2008. Hemicellulose biorefineries: a review on biomass pretreatments. J. Sci. Ind. Res., 67, 849-864.

3. Karunanithy C. and Muthukumarappan K. 2010. Influence of extruder temperature and screw speed on pretreatment of corn stover while varying enzymes and their ratios. Appl. Biochem. Biotechnol., 162, 264-279.

4. Menardo S., Cacciatorea V., Balsaria P. 2015. Batch and continuous biogas production arising from feed varying in rice straw volumes following pre-treatment with extrusion, Bioresour. Technol., 180, 154-161.

5. Norm DIN 38 414-S8, 1985. Characterisation of the substrate, sampling, collection of material data, fermentation tests, Deutsches Institut für Normung, Berlin.

6. Norm VDI 4630, 2006. Vergärung organischer Stoffe Substratcharakterisierung, Probenahme, Stoffdatenerhebung, Gärversuche (in German). Fermentation of organic materials characterization of the substrate, sampling, collection of material data, fermentation tests (in English). Düsseldorf: Verein Deutscher Ingenieure - German Engineers Club.

7. Uellendahl H., Wang G., Mřller H.B., Jrrrgensen U., Skiadas V., Gavala H.M., Ahring B.K. 1998. Energy balance and cost-benefit analysis of biogas production from perennial energy crops pretreated by wet oxidation. Water Sci. Technol., 58, 1841-1847.

8. Panepinto D., Genon G. 2016. Analysis of the extrusion as a pretreatment for the anaerobic digestion process. Ind. Crops Prod., 83, 206-212.

9. Parkin G.F. and Owen W.F. 1986. Fundamentals of anaerobic digestion of wastewater sludges, J. Environ. Eng., 112, 867-920.

10. Pérez J., Muñoz-Dorado J., Rubia T.,Ć J. Martínez J. 2002. Biodegradation and biological treatments of cellulose, hemicellulose and lignin: an overview. Int. Microbiol., 5, 53-63.

11. Pęksa A. 2011. Ekstruzja jako metoda produkcji wyrobów ekspandowanych. Uniwersytet Przyrodniczy, Wrocław.

12. Pilarska A., Pilarski K., Witaszek K., Dukiewicz H., Dobrzański K., 2015. Wstępne badania wpływu obróbki termicznej kiszonki z kukurydzy na wydajność biogazową. Nauka Przyr. Technol., 9(2), pp. 18.

13. Pilarska A.A., Pilarski K., Witaszek K., Waliszewska H., Zborowska M., Waliszewska B., Kolasiński M., Szwarc-Rzepka K. 2016. Treatment of dairy waste by anaerobic digestion with sewage sludge. Ecol. Chem. Eng. S, 23(1), 99-115.

14. Stolarski M., J., Krzyżaniak M., Waliszewska B., Szczukowski S., Tworkowski J., Zborowska M. 2013. Lignocellulosic biomass derived from agricultural land as industrial and energy feedstock. Drewno. Pr. Nauk. Donies. Komunik., 56, 5-23.

15. Witaszek K., Krysztofiak A., Pilarski K., Pilarska A.A. 2015. Przegląd metod obróbki wstępnej substratów biogazowych. Techn. Roln. Ogrod. Leśna, $6,5-7$.

16. Witaszek K., Pilarska A., Pilarski K. 2015. Wybrane metody wstępnej obróbki surowców roślinnych stosowanych do produkcji biogazu. Ekonomia i Środ., 2(53), 130-144.

17. Yang L., Xu F., Ge X., Li Y. 2015. Challenges and strategies for solid-state anaerobic digestion of lignocellulosic biomass. Renew. Sustain. Energy Rev., 44, 824-834.

18. Yitbarek M.B., Tamir B. 2014. Silage additives: review. Open J. Appl. Sci., 4, 258-274.

19. Zheng Y., Zhao J., Xu F., Li. Y. 2014. Pretreatment of lignocellulosic biomass for enhanced biogas production. Prog. in Energy Comb. Sci., 42, 35-53. 